Original Research Paper

\title{
Comparison of Compertz and Logistic Models in Estimating the Growth of Leptin-Deficient (ob/ob) Mice and Wild-Type Mice Fed an In-House Prepared High-Fat Diet
}

\author{
${ }^{1,2}$ Ah Reum Son, ${ }^{1,2}$ Hyunwoong Jo, ${ }^{1}$ Kyu Ree Park and ${ }^{1,2}$ Beob Gyun Kim \\ ${ }^{I}$ Department of Animal Science and Technology, Konkuk University, Seoul, Republic of Korea \\ ${ }^{2}$ Monogastric Animal Feed Research Institute, Konkuk University, Seoul, Republic of Korea
}

\author{
Article history \\ Received: 10-11-2018 \\ Revised: 2-01-2019 \\ Accepted: 18-01-2019 \\ Corresponding Author: \\ Beob Gyun Kim \\ Department of Animal Science \\ and Technology, \\ Konkuk University, Seoul, \\ Republic of Korea \\ Email: bgkim@konkuk.ac.kr
}

\begin{abstract}
This experiment was conducted to growth curve models for leptindeficient $(o b / o b)$ and wild-type mice fed a meal-form High-Fat (HF) diet prepared in-house for over 120 weeks. Two hundred and twenty-four sets of Body Weight (BW) and age data were collected from $o b / o b$ mice and 485 sets of data were collected from wild-type mice. All animals had free access to the HF diet (34.3\% energy from fat) and water. Individual BW and survival rates of mice were measured. To develop growth curves of $o b / o b$ mice and wild-type mice fed the HF diet, Gompertz and Logistic growth models were employed. The survival rates of $o b / o b$ mice fed the HF diet were lower than those of wild-type mice. Models for estimating growth of $o b / o b$ mice fed the HF diet were: $\mathrm{BW}, \mathrm{g}=61.36 \times \mathrm{e}^{-2.56 \times \mathrm{e}^{\curlywedge}-0.13 \mathrm{t}}$ in Gompertz model (Akaike's Information Criterion, AIC $=1,694$ ); and BW, $\mathrm{g}=60.65 \times$ $\left(1+7.04 \times \mathrm{e}^{-0.18 t}\right)^{-1}$ in Logistic model (AIC $\left.=1,719\right)$. Growth models for wild-type mice fed the HF diet were: $\mathrm{BW}, \mathrm{g}=28.94 \times \mathrm{e}^{-1.75 \times \mathrm{e}^{\wedge}-0.13 \mathrm{t}}$ in Gompertz model (AIC $=3,171)$; and BW, $g=28.23 \times\left(1+4.85 \times \mathrm{e}^{-0.25 t}\right)^{-1}$ in Logistic model (AIC $=3,198)$. In conclusion, Gompertz models may be more appropriate to estimate the growth of $o b / o b$ mouse fed the diet with high-fat concentration.
\end{abstract}

Keywords: Gompertz Model, Growth Curve, High-Fat Diet, Logistic Model $o b / o b$ mice

\section{Introduction}

Many obese models used in obesity or obesity-related disease research are gene-specific knockout or transgenic rodents and the obese model animals are often fed HighFat (HF) diets (Woods et al., 2003; Buettner et al., 2007). Commercial pellet-type HF diets have been widely used to induce and maintain obesity in mouse models. In many nutrition experiments for testing dietary supplements, on the other hand, meal-form diets are preferred due to the convenience in preparing experimental diets (Niu et al., 2017; Elkahoui et al., 2018). However, meal-form HF diets for rodents are rarely available.

As elderly population increases, research on obese elderly men and women becomes more and more important (Vioque et al., 2007; Sardeli et al., 2018). Although young obese mice mostly less than 20 weeks of age are often used in nutrition research, older mice are more appropriate for mimicking adult or elderly human obesity and thus, have been recently used in elderly obesity research (Hunsche et al., 2016; Frasca et al., 2017). However, information on the survival rate and Body Weight (BW) changes of leptin-deficient (ob/ob) mice fed a HF diet for over 6 months is very limited. Therefore, the objectives of the present work were to test a novel meal-form $\mathrm{HF}$ diet fed to mice and to develop growth curve models for $o b / o b$ and wild-type mice fed a meal-form HF diet for over 120 weeks.

\section{Materials and Methods}

Animals and Experimental Diet

Two hundred and twenty-four sets of BW and age data were collected from $o b / o b$ mice and 485 sets of data were collected from wild-type mice. Body weight and age ranged from 6.3 to $77.7 \mathrm{~g}$ and from 3 to 127 weeks, respectively. 
A HF diet (34.3\% energy from fat) was prepared inhouse to contain $49 \%$ ground corn, $30 \%$ soybean meal (crude protein $48 \%$ ), 20\% fat powder and 1\% vitaminmineral premix (Table 1). The fat powder is a proteincoated fat product that was mainly composed of $80 \%$ lard, whey and casein. All animals had free access to diet and water. Individual BW of mice was measured with approximately two-week intervals.

\section{Growth Models and Statistical Analysis}

For estimating the growth curves for $o b / o b$ and wild-type mice, the NLMIXED procedure of SAS (SAS Inst. Inc., Cary, NC, USA) with nonlinear regression was used. The model equation used for the Gompertz model (Gompertz, 1825) is:

$$
W t(g)=A e^{-b e^{\wedge-k t}}
$$

The model equation used the Logistic model (Robertson, 1908) is:

$$
W t(g)=A\left(1+b e^{-k t}\right)-1
$$

For both equations, 3 parameters in the equation were employed to estimate the growth model parameters in which $W t$ is the BW of mice at time $t$ (week), $A$ is the mature weight, $b$ is the growth ratio, $k$ is the maturing rate; and $e$ is the natural logarithm. Based on the estimated 3 parameters, the age at point of inflection, gain at inflection and weight at inflection were calculated.

In the Gompertz model, equations for the age at point of inflection $\left(t_{i}\right)$, body weight at inflection $\left(W t_{i}\right)$ and gain at inflection $(\delta W t / \delta t)$ are:

$$
\begin{gathered}
t_{i}=\left(\log _{\mathrm{e}} b\right) / k \\
W t_{i}=A / e \\
d y_{i} / d t_{i}=k b W t_{i} e^{-k t}
\end{gathered}
$$

Table 1: Ingredients composition and calculated gross energy contents of high-fat diet

\begin{tabular}{lr}
\hline Item & High-fat diet \\
\hline Ingredient, \% & \\
Ground corn & 49 \\
Soybean meal (crude protein, 48\%) & 30 \\
Fat powder (ether extract, 80\%) & 20 \\
Vitamin-mineral premix & 1 \\
Gross energy, kcal/kg & 4,891 \\
\hline
\end{tabular}

a Provided the following quantities per $\mathrm{kg}$ of complete diet: vitamin $\mathrm{A}, 50,000 \mathrm{IU}$; vitamin $\mathrm{D}_{3}, 8,000 \mathrm{IU}$; vitamin $\mathrm{E}, 100 \mathrm{U}$; vitamin $\mathrm{K}, 10.0 \mathrm{mg}$; thiamin, $9.8 \mathrm{mg}$; riboflavin, $20.0 \mathrm{mg}$; pyridoxine, $9.8 \mathrm{mg}$; vitamin $\mathrm{B}_{12}, 0.12 \mathrm{mg}$; pantothenic acid, $75.0 \mathrm{mg}$; folic acid, $2.20 \mathrm{mg}$; niacin, $124 \mathrm{mg}$; biotin, $0.12 \mathrm{mg}$; $\mathrm{Cu}, 50 \mathrm{mg}$ as copper sulfate; Fe, $536 \mathrm{mg}$ as iron sulfate; I, 10.0 $\mathrm{mg}$ as potassium iodate; $\mathrm{Mn}, 250 \mathrm{mg}$ as manganese sulfate; Se, $0.76 \mathrm{mg}$ as sodium selenite; $\mathrm{Zn}, 626 \mathrm{mg}$ as zinc oxide; butylated hydroxytoluene, $100 \mathrm{mg}$
In the Logistic model, equations for the $t_{i}, W t_{i}$ and $\delta W t / \delta t$ are:

$$
\begin{gathered}
t_{i}=\left(\log _{\mathrm{e}} b\right) / k \\
W t_{i}=A / 2 \\
d y_{i} / d t_{i}=A b k e^{k t i} /\left(e^{k t i}+b\right)^{2}
\end{gathered}
$$

The inflection point, second derivative of function, means where the slope of the growth curve becomes maximum.

\section{Results}

The ob/ob mice gained more weight compared with the wild-type mice, and a hair loss was found on the neck area of $o b / o b$ mice (Fig. 1). The survival rate of the $o b / o b$ mice was lower than that of the wild-type mice (Fig. 2).

The average mature $\mathrm{BW}$ of $o b / o b$ mice estimated from the Gompertz and Logistic models was approximately $61.0 \mathrm{~g}$ (Table 2; Fig. 3 and 4). The average mature $\mathrm{BW}$ of wild-type mice estimated from the models was approximately $28.6 \mathrm{~g}$. The age at point of inflection, BW at inflection and gain at inflection are presented in Table 3. The average BW at inflection of $o b / o b$ and wild-type mice estimated from the models was approximately 26.5 and $12.4 \mathrm{~g}$, respectively.

\section{Discussion}

It has been reported that the obesity of $o b / o b$ mice can be visually identified after 4 weeks of age (Kennedy et al., 2010), and physical differences between the $o b / o b$ and wild-type mice were also observed in the present study. Moreover, the wildtype mice had more sleek hairs and active movements than $o b / o b$ mice in this study. This observation is supported by previous studies that reported critical role of leptin in hair cycle (Sumikawa et al., 2014; Tasaki et al., 2015; Sasaki et al., 2018). After depilation, elongation of telogen was observed in $o b / o b$ mice compared with the wild-type mice (Tasaki et al., 2015). Moreover, the $o b / o b$ mice and mice fed the high-fat diet suffered delayed wound closure (Seitz et al., 2010).

The lower survival rates of $o b / o b$ mice compared with wild-type mice agreed with previous studies. Ren et al. (2010) reported reduced survival rates of the $o b / o b$ mice compared with wild-type mice. In addition, the survival rate began to decline from 50 weeks of age $\mathrm{ob} / \mathrm{ob}$ mice in the present study. This result agreed with Harrison and Archer (1987) reporting that the ob/ob mice showed high mortality after 52 weeks of age. 


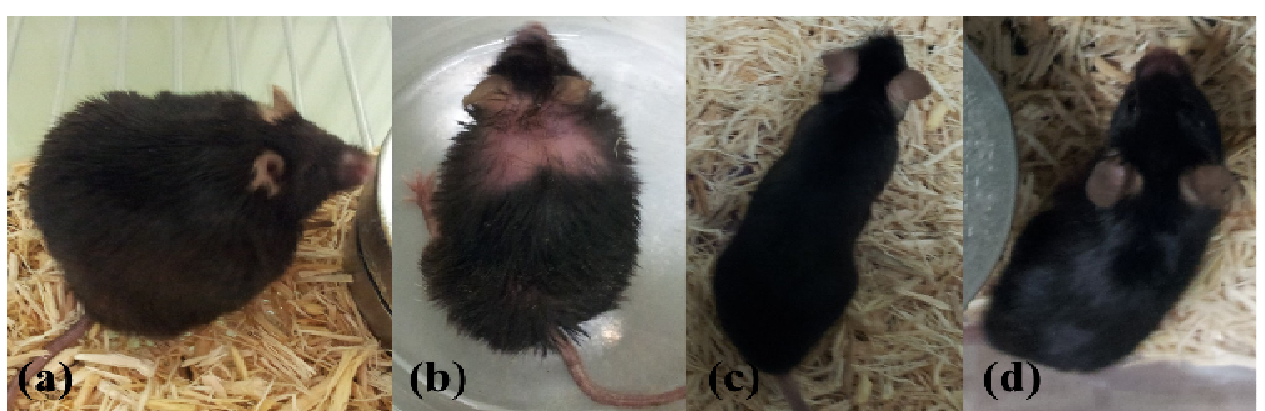

Fig. 1: Leptin-deficient (ob/ob) mice (a and b) and wild-type mice (c and d) fed a high-fat diet

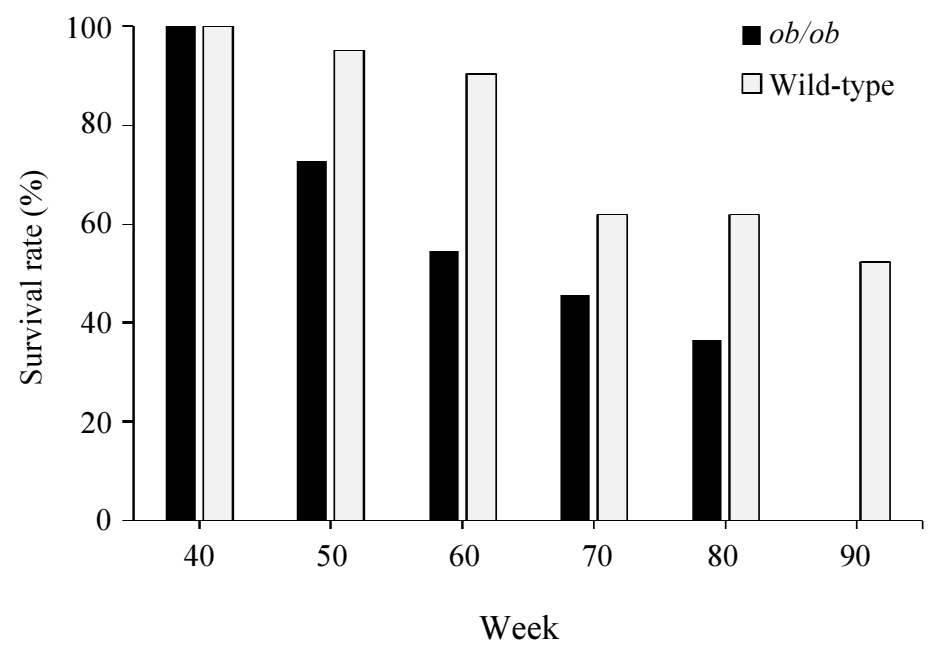

Fig. 2: The survival rates of $o b / o b$ and wild-type mice fed a high-fat diet

Table 2: Estimates of growth curve parameters for leptin-deficient ( $o b / o b)$ and wild-type mice using Gompertz and Logistic models as a function of age (week)

\begin{tabular}{|c|c|c|c|c|c|}
\hline \multirow[b]{2}{*}{ Genotype } & \multirow[b]{2}{*}{ Growth model } & \multicolumn{3}{|l|}{ Parameters $^{\mathrm{a}}$} & \multirow[b]{2}{*}{$\mathrm{AIC}^{\mathrm{b}}$} \\
\hline & & $A \pm \mathrm{SE}$ & $b \pm \mathrm{SE}$ & $k \pm \mathrm{SE}$ & \\
\hline \multirow[t]{2}{*}{$\overline{o b / o b}$} & Gompertz $^{\mathrm{c}}$ & $61.36 \pm 0.66$ & $2.56 \pm 0.17$ & $0.13 \pm 0.01$ & 1,694 \\
\hline & Logistic $^{\mathrm{d}}$ & $60.65 \pm 0.65$ & $7.04 \pm 0.88$ & $0.18 \pm 0.01$ & 1,719 \\
\hline \multirow[t]{2}{*}{ Wild-type } & Gompertz & $28.94 \pm 0.36$ & $1.75 \pm 0.15$ & $0.13 \pm 0.02$ & 3,171 \\
\hline & Logistic & $28.23 \pm 0.33$ & $4.85 \pm 1.31$ & $0.25 \pm 0.06$ & 3,198 \\
\hline
\end{tabular}

${ }^{\mathrm{a}} A=$ mature body weight; $b=$ growth rate; $k=$ maturing rate; $\mathrm{SE}=$ Standard Error

bAkaike's information criterion

${ }^{\mathrm{c}}$ Gompertz model: body weight, $\mathrm{g}=A e^{-b e^{\wedge}-k t}$

${ }^{\mathrm{d}}$ Logistic model: body weight, $\mathrm{g}=A\left(1+b e^{-k t}\right)^{-1}$

Table 3: Characteristics at inflection point on growth curves using Gompertz and Logistic models for leptin-deficient (ob/ob) and wild-type mice as a function of age

\begin{tabular}{lllll}
\hline Genotype & Growth model & $\begin{array}{l}\text { Age at point of } \\
\text { inflection }^{\mathrm{a}}(\text { week })\end{array}$ & $\begin{array}{l}\text { Body weight at } \\
\text { inflection }^{\mathrm{b}}(\mathrm{g})\end{array}$ & $\begin{array}{l}\text { Gain at inflection }^{\mathrm{c}} \\
(\mathrm{g} / \text { week }\end{array}$ \\
\hline ob/ob & Gompertz & 7.22 & 22.57 & 2.93 \\
& Logistic & 10.70 & 30.33 & 2.77 \\
Wild-type & Gompertz & 4.19 & 10.65 & 1.43 \\
& Logistic & 6.31 & 14.11 & 1.76 \\
\hline
\end{tabular}

${ }^{\mathrm{a}}$ Age at point of inflection $=\left(\log _{\mathrm{e}} b\right) / k$

${ }^{\mathrm{b}}$ Body weight at inflection for Gompertz model $=A / e$; body weight at inflection for Logistic model $=A / 2$

${ }^{\mathrm{c}}$ Gain at inflection for Gompertz model $=k b W t_{i} e^{-k t}$; gain at inflection for Logistic model $=A b k e^{k t i} /\left(e^{k t i}+b\right)^{2}$ 


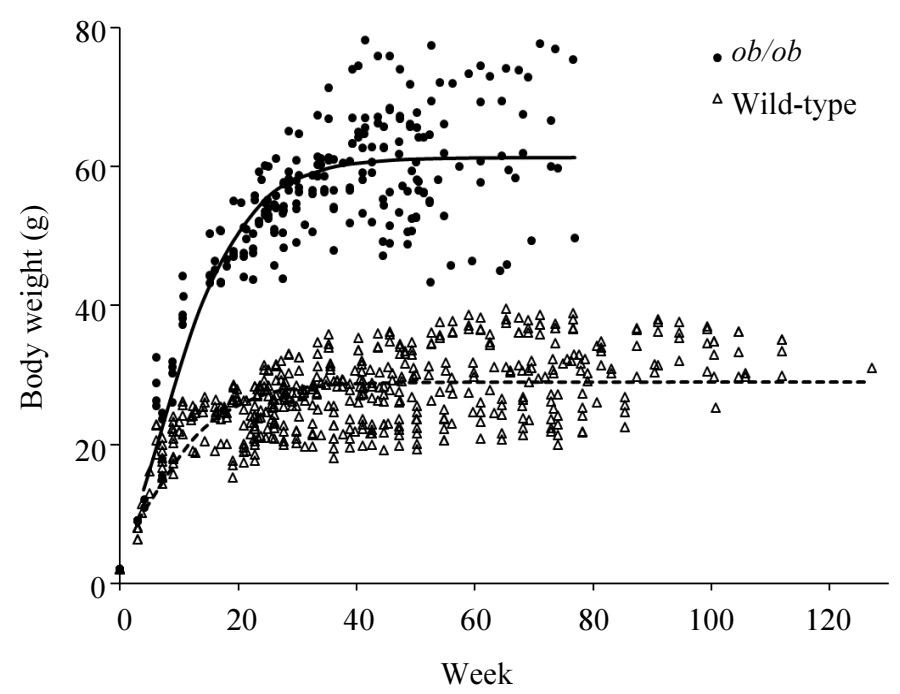

Fig. 3: Gompertz models of estimated Body Weight (BW) growth of mice fed a high-fat diet as a function of age: BW of leptindeficient $(o b / o b)$ mice, $g=61.36 \times \mathrm{e}^{-2.56 \times \mathrm{e}^{-0}-13 \mathrm{t}}$ with Akaike's Information Criterion $(\mathrm{AIC})=1,694$; BW of wild-type mice, $\mathrm{g}$ $=28.94 \times \mathrm{e}^{-1.75 \times \mathrm{e}^{\wedge}-0.13 \mathrm{t}}$ with $\mathrm{AIC}=3,171$

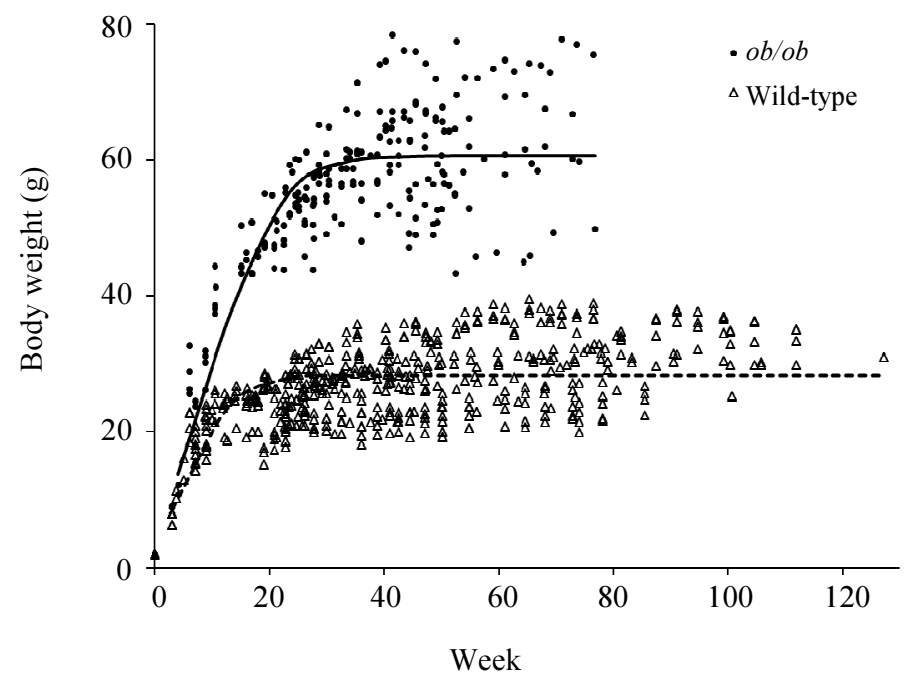

Fig. 4: Logistic models of estimated Body Weight (BW) growth of mice fed high-fat diets as a function of age: BW of leptindeficient $(o b / o b)$ mice, $g=60.65 \times \mathrm{e}^{-7.04 \times \mathrm{e}^{\curlywedge}-0.18 \mathrm{t}}$ with Akaike's Information Criterion $(\mathrm{AIC})=1,717$; BW of wild-type mice, $g=28.23 \times \mathrm{e}^{-4.85 \times \mathrm{e}^{\wedge}-0.25 \mathrm{t}}$ with $\mathrm{AIC}=3,198$

The greater mature $\mathrm{BW}$ of $o b / o b$ mice than wildtype mice was observed in the present study. In both modes, the growth rate of the $o b / o b$ mice was also greater compared with that of the wild-type mice. While the $o b / o b$ mice reach the maximum BW of 60 to $70 \mathrm{~g}$ at 28 to 32 weeks, the lean-type mice reach the maximum BW of 30 to $40 \mathrm{~g}$ at 12 to 16 weeks (Hedrich, 2012). Greater energy and nutrient intake may have contributed to the rapid growth rate of $o b / o b$ mice used in this study. Murphy et al. (2010) reported that the $o b / o b$ mice gained more weight compared with lean mice, resulted from greater accumulative energy intake in the $o b / o b$ mice. Moreover, a previous study reported that increases in weight gain and feed intake of the $o b / o b$ mice fed HF diets containing corn oil or beef tallow were observed compared with the $o b / o b$ mice fed a low-fat diet (Mercer and Trayhurn, 1987). In addition, the magnitude of increase was greater in the $o b / o b$ mice than lean mice. Generally, the model with a lower value for Akaike's information criterion can be considered as a more appropriate model (Gbangboche et al., 2008). Based on the values for Akaike's information criterion, the 
Gompertz model was more appropriate for estimating BW of $o b / o b$ and wild-type mice.

In the present study, the age at point of inflection, $\mathrm{BW}$ at inflection and gain at inflection were greater in the $o b / o b$ mice compared with the wild-type mice. The greater $\mathrm{BW}$ and rapid growth rate of $o b / o b$ mice compared with wild-type mice have also been reported in the literature (Harris et al., 1998; Sainsbury et al., 2002; Sun et al., 2006; Seitz et al., 2010).

\section{Conclusion}

In conclusion, the Gompertz models are more appropriate for estimating the growth of mice fed a highfat diet compared with Logistic models. The suggested growth curves and survival rate data for leptin-deficient mice fed a high-fat diet can be used for designing longterm experiments or planning to use elderly obesity models. Additionally, the high-fat diet formula for mealform feeds provided in the present work is useful in nutrition experiments employing leptin-deficient mice. Further research is warranted to develop growth models for other model animals for obesity or nutrition research.

\section{Acknowledgement}

The authors are grateful to Yeowool $\mathrm{Na}$ for animal care and data recording.

\section{Author's Contributions}

Ah Reum Son: Conducted the animal experiment and drafted most of the manuscript.

Hyunwoong Jo: Performed statistical analysis and critically revised statistical part of the manuscript.

Kyu Ree Park: Assisted animal care and data recording and prepared figures and tables.

Beob Gyun Kim: Supervised the experimental work and manuscript preparation and revised the manuscript.

\section{Ethics}

The authors declared no ethical issues.

\section{References}

Buettner, R., J. Schölmerich and L.C. Bollheimer, 2007. High-fat diets: Modeling the metabolic disorders of human obesity in rodents. Obesity, 15: 798-808. DOI: $10.1038 /$ oby.2007.608

Elkahoui, S., G.E. Bartley, W.H. Yokoyama and M. Friedman, 2018. Dietary supplementation of potato peel powders prepared from conventional and organic russet and non-organic gold and red potatoes reduces weight gain in mice on a high-fat diet. J. Agric. Food Chem., 66: 6064-6072. DOI: $10.1021 /$ acs.jafc. 8 b01987
Frasca, D., A. Diaz, M. Romero, T. Vazquez and B.B. Blomberg, 2017. Obesity induces pro-inflammatory $B$ cells and impairs B cell function in old mice. Mech. Ageing Dev., 162: 91-99. DOI: 10.1016/j.mad.2017.01.004

Gompertz, B., 1825. On the nature of the function expressive of the law of human mortality and on a new mode of determining the value of life contingencies. Philos. Trans. R. Soc. Lond., 115: 513-585. DOI: 10.1098/rstl.1825.0026

Gbangboche, A.B., R. Glele-Kakai, S. Salifou, L.G. Albuquerque and P.L. Leroy, 2008. Comparison of non-linear growth models to describe the growth curve in West African Dwarf sheep. Animal, 2: 1003-1012. DOI: 10.1017/S1751731108002206

Harrison, D.E. and J.R. Archer, 1987. Genetic differences in effects of food restriction on aging in mice. J. Nutr., 117: 376-382.

DOI: $10.1093 / \mathrm{jn} / 117.2 .376$

Harris, R.B.S., J. Zhou, S.M. Jr. Redmann G.N. Smagin and S.R. Smith, et al., 1998. A leptin dose-response study in obese $(o b / o b)$ and lean $(+/ ?)$ mice. Endocrinology, 139: 8-19. DOI: 10.1210 /endo.139.1.5675

Hedrich, H.J., 2012. The Laboratory Mouse. 2nd Edn., Elsevier Academic Press, Amsterdam, The Netherlands, ISBN-10: 9780123820082, pp: 588.

Hunsche, C., O. Hernandez and M. De la Fuente, 2016. Impaired immune response in old mice suffering from obesity and premature immunosenescence in adulthood. J. Gerontol. A Biol. Sci. Med. Sci., 71: 983-991.

DOI: $10.1093 /$ gerona/glv082

Kennedy, A.J., K.L.J. Ellacott, V.L. King and A.H. Hasty, 2010. Mouse models of the metabolic syndrome. Dis. Model. Mech., 3: 156-166. DOI: $10.1242 / \mathrm{dmm} .003467$

Mercer, S.W. and P. Trayhurn, 1987. Effect of high fat diets on energy balance and thermogenesis in brown adipose tissue of lean and genetically obese $o b / o b$ mice. J. Nutr., 117: 2147-2153. DOI: $10.1093 / \mathrm{jn} / 117.12 .2147$

Murphy, E.F., P.D. Cotter, S. Healy, T.M. Marques and O. O'Sullivan et al., 2010. Composition and energy harvesting capacity of the gut microbiota: Relationship to diet, obesity and time in mouse models. Gut, 59: 1635-1642.

DOI: 10.1136/gut.2010.215665

Niu, M., L. Xiang, Y. Liu, Y. Zhao and J. Yuan, et al., 2017. Adiponectin induced AMP-activated protein kinase impairment mediates insulin resistance in Bama mini-pig fed high-fat and high-sucrose diet. Asian-Australas. J. Anim. Sci., 30: 1190-1197. DOI: 10.5713/ajas.17.0006 
Ren, J., F. Dong, G.J. Cai, P. Zhao and J.M. Nun et al., 2010. Interaction between age and obesity on cardiomyocyte contractile function: Role of leptin and stress signaling. PLoS ONE, 5: e10085.

DOI: 10.1371 /journal.pone.0010085

Robertson, T.B., 1908. On the normal rate of growth of an individual and its biochemical significance. Arch. Entwickl. Org., 25: 581-614. DOI: $10.1007 / \mathrm{BF} 02163864$

Sainsbury, A., C. Schwarzer, M. Couzens and H. Herzog, 2002. Y2 receptor deletion attenuates the type 2 diabetic syndrome of $o b / o b$ mice. Diabetes, 51: 3420-3427. DOI: 10.2337/diabetes.51.12.3420

Sardeli, A.V., T.R. Komatsu, M.A. Mori, A.F. Gáspari and M.P.T. Chacon-Mikahil, 2018. Resistance training prevents muscle loss induced by caloric restriction in obese elderly individuals: A systematic review and meta-analysis. Nutrients, 10: 423. DOI: $10.3390 /$ nu 10040423

Sasaki, M., S. Shinozaki, H. Morinaga, M. Kaneki and E. Nishimura et al., 2018. iNOS inhibits hair regeneration in obese diabetic $(o b / o b)$ mice. Biochem. Biophys. Res. Commun., 501: 893-897. DOI: $10.1016 /$ j.bbrc.2018.05.071
Sumikawa, Y., S. Inui, T. Nakajima and S. Itami, 2014. Hair cycle control by leptin as a new anageninducer. Exp. Dermatol., 23: 27-32. DOI: 10.1111/exd.12286

Sun, Y., M. Asnicar, P.K. Saha, L. Chan and R.G. Smith, 2006. Ablation of ghrelin improves the diabetic but not obese phenotype of $o b / o b$ mice. Cell Metab., 3: 379-386. DOI: 10.1016/j.cmet.2006.04.004

Tasaki, N., T. Minematsu, Y. Mugita, S. Ikeda and G. Nakagami et al., 2015. Telogen elongation in the hair cycle of $o b / o b$ mice. Biosci. Biotechnol. Biochem., 80: 74-79. DOI: 10.1080/09168451.2015.1069693

Vioque, J., T. Weinbrenner, L. Asensio, A. Castelló and I.S. Young et al., 2007. Plasma concentrations of carotenoids and vitamin $\mathrm{C}$ are better correlated with dietary intake in normal weight than overweight and obese elderly subjects. Br. J. Nutr., 97: 977-986. DOI: $10.1017 / \mathrm{S} 0007114507659017$

Woods, S.C., R.J. Seeley, P.A. Rushing, D. D'Slessio and P. Tso, 2003. A controlled high-fat diet induces an obese syndrome in rats. J. Nutr., 133: 1081-1087. DOI: $10.1093 / \mathrm{jn} / 133.4 .1081$ 